Reprod. Nutr. Dévelop., 1984, 24 (6), 835-843.

\title{
In vivo milk digestion in the calf abomasum. II. Milk and whey proteolysis
}

\author{
Mireille YVON, Isabelle VAN HILLE, J.-P. PÉLISSIER (1), \\ P. GUILLOTEAU ( $\left.{ }^{*}\right)$, R. TOULLEC (*)
}

Laboratoire de Biochimie et Technologie Laitières, I.N.R.A., 78350 Jouy-en-Josas, France.

(*) Station de Recherches sur les jeunes Bovins, I.N.R.A. 65, rue de St-Brieuc, 35042 Rennes Cedex, France.

Summary. The peptide products insoluble in $12 \%$ TCA collected in the proximal duodenum of calves at different times after ingestion of milk, skim-milk or whey were characterized by polyacrylamide gel electrophoresis, isoelectric focusing and SDS-pore gradient gel electrophoresis. $\beta$-Lactoglobulin and $\alpha$-lactalbumin were determined by rocket immunoelectrophoresis.

The presence of fat did not modify the hydrolysis of milk proteins. Casein coagulation occurred very quickly and the peptides derived from caseins, which arrived slowly in the gut, reflected a fairly high proteolysis. The presence of casein in the diet did not modify gastric proteolysis of whey proteins. The $\beta$-lactoglobulin was degraded poorly or not at all, and $\alpha$-lactalbumin was slowly but completely hydrolized in peptides which had lost their immunoreactive properties.

\section{Introduction.}

In preruminant calves, the first step of protein digestion occurs in the abomasum. Gastric proteolysis is due to pepsins and chymosin (Berridge et al., 1943 ; Garnot et al., 1977). It has been shown that these enzymes rapidly cleave the Phe 105-Met 106 bond in K-casein (Delfour, Alais and Jolles, 1966) and that this single splitting is responsible for milk clotting. Without calcium, the same proteolysis does not cause coagulation (Porcher, 1930). Thus, casein digestion should be different in calves fed milk or casein diets.

(1) All correspondances to : J.-P. Pélissier, I.N.R.A., Laboratoire de Biochimie et Technologie laitières, 78350 Jouy-en-Josas, France. 
In a previous work (Pélissier et al., 1983), gastric emptying in preruminant calves fed milk or whole-casein solutions was studied by determination of the $\mathbf{N}$ content of soluble and insoluble fractions in $12 \%$ TCA. Peptide products which appeared in the proximal duodenum of calves at different times after the ingestion of casein solutions have been characterized (Yvon et al., 1984). In the present work, we studied peptide products, collected in the same conditions as previously, in calves fed whole milk, skim-milk and whey.

\section{Material and methods.}

The feeding of the calves and the collection procedures were as previously described (Pélissier et al., 1983; Yvon et al., 1984). Each animal, fitted with a duodenal cannula, received $5 \mathrm{~kg}$ of a test meal. All digesta leaving the stomach during the first 7 postprandial hours were collected fractionally every $10 \mathrm{~min}$ during the first hour, every $15 \mathrm{~min}$ during the second hour and every $30 \mathrm{~min}$ during the 7th hour.

Three diets were prepared from the same milk : whole milk (diet A), skimmilk (diet B) and whey (diet C).

Each samples of digesta was precipitated with trichloracetic acid (TCA) to $12 \%$ final concentration and centrifuged at $2000 \times \mathrm{g}$ for $20 \mathrm{~min}$. After homogenization in water, the sediment was extracted 10 times with an equal volume of diethylether to eliminate the TCA, and then lyophilized.

The sediments were analysed by polyacrylamide gel electrophoresis (PAGE), isoelectric focusing (IEF) and SDS-pore gradient gel electrophoresis (SDS-PGGE). The major whey proteins ( $\beta$-lactoglobulin and $\alpha$-lactalbumin) were determined by rocket immunoelectrophoresis (RIE) in casein (obtained by precipitation of milk at $\mathrm{pH}$ 4.6), milk and whey.

PAGE was performed according to Uriel (1966) and Gripon et al. (1975). IEF and SDS-PGGE were performed according to Trieu-Cuot and Gripon (1981). RIE was performed according to Laurell (1966).

\section{Results.}

The diets $A$ and $B$ gave very similar patterns with all the techniques used; the electrophoretic band corresponding to the major caseins $\left(\alpha_{s 1}\right.$ and $\left.\beta\right)$ in PAGE disappeared completely as early as the second sample collected (fig. 1). On the other hand, the electrophoretic bands corresponding to the migration front were observed after about $3 \mathrm{~h}$ of digestion and up to $7 \mathrm{~h}$. The major whey protein $(\beta$ lactoglobulin) was visible in all the samples, even after about $3 \mathrm{~h}$ when electrophoretic band that we identified as $\alpha$-lactalbumin had disappeared. With diet $C$ (fig. 2), the electrophoretic bands corresponding to the caseins were not observed in the first sample and there was no product moving with the migration front. 


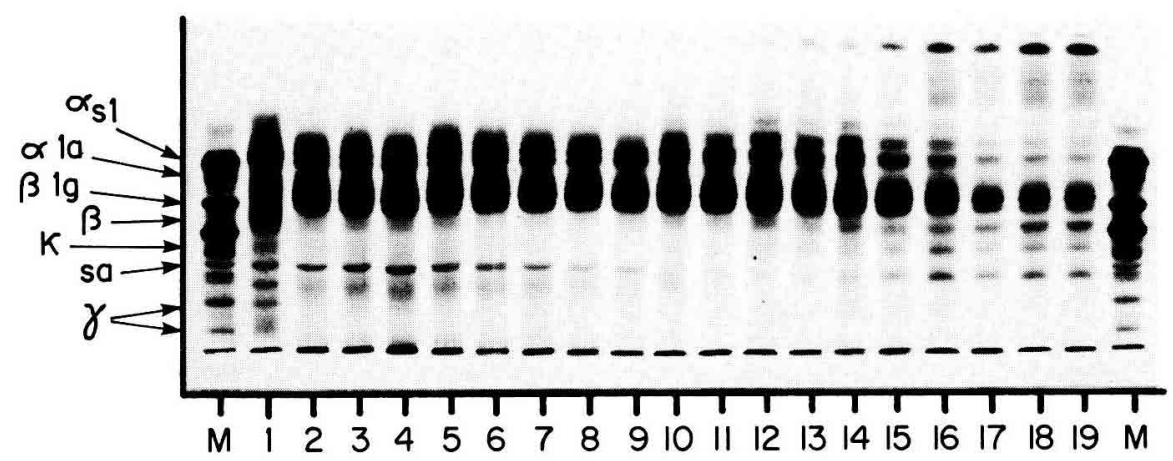

FIG. 1. - Polyacrylamide-agarose gel electrophoresis of samples obtained with diet $A$. $\mathrm{M}:$ milk. Times of sample collection : $1: 0-10 \mathrm{~min} ; 2: 10-20 \mathrm{~min} ; 3: 20-30 \mathrm{~min}$; $4: 30-40 \mathrm{~min} ; 5: 40-50 \mathrm{~min} ; 6: 50-60 \mathrm{~min} ; 7: 60-75 \mathrm{~min} ; 8: 75-90 \mathrm{~min} ; 9: 90-105 \mathrm{~min}$; 10: $105-120 \min ; 11: 2 \mathrm{~h}-2 \mathrm{~h} 30 ; 12: 2 \mathrm{~h} 30-3 \mathrm{~h} ; 13: 3 \mathrm{~h}-3 \mathrm{~h} 30 ; 14: 3 \mathrm{~h} 30-4 \mathrm{~h}$; $15: 4$ h-4 h $30 ; 16: 4$ h $30-5$ h ; $17: 5$ h-5 h $30 ; 18: 5$ h $30-6$ h ; $19: 6$ h-6 h $30 ; 20: 6$ h $30-7$ h.

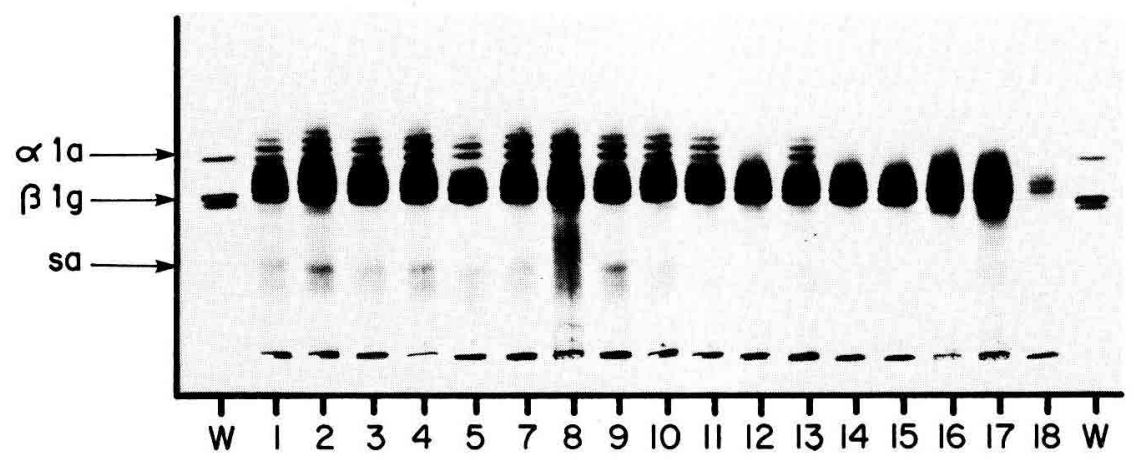

FIG. 2. - Polyacrylamide-agarose ge/ electrophoresis of samples obtained with diet $C$. See legend of figure 1.

These results were confirmed by IEF. Except for the bands corresponding to whey proteins, a large number of widely distributed $p$ l values were apparent with diets $A$ and $B$ (fig. 3). A group of acid peptides appeared at the same rate as products which moved with the migration front in PAGE. With diet $C$ these acid bands were not visible (fig. 4).

The molecular weights (MW) of peptides collected in the duodenum were determined by SDS-PGGE. With the milk diets, the caseins could be identified only in the first sample (0-10 min) collected (fig. 5). The peptides which appeared during the digestion of diets $A$ and $B$ had fairly low MW's but were still insoluble in $12 \%$ TCA. The samples collected with the three diets used (figs. 5,6 ) showed little or no degradation of $\beta$-lactoglobulin. On the other hand, SDS-PGGE confirmed that $\alpha$-lactalbumin disappeared after about $3 \mathrm{~h}$, probably being 


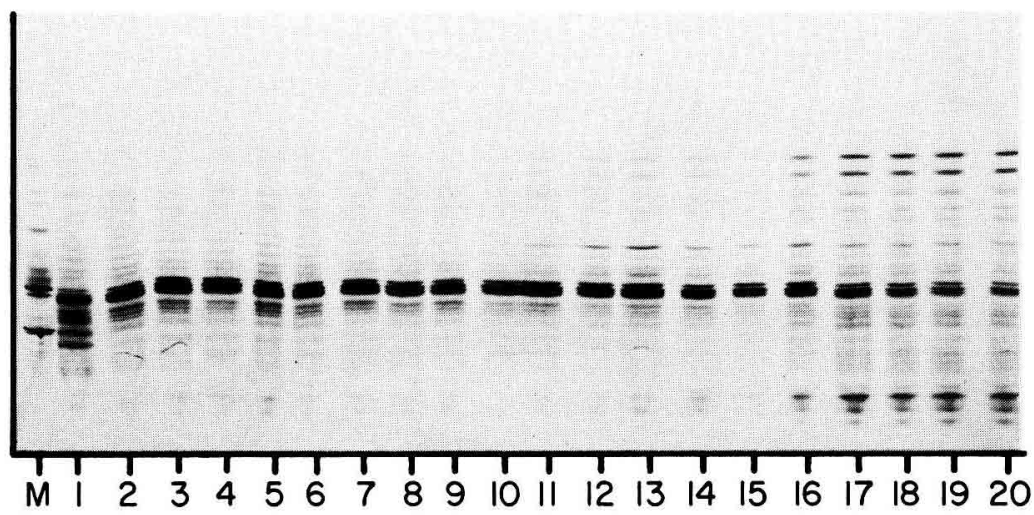

FIG. 3. - Isoelectrofocusing of samples obtained with diet $A$. See legend of figure 1.

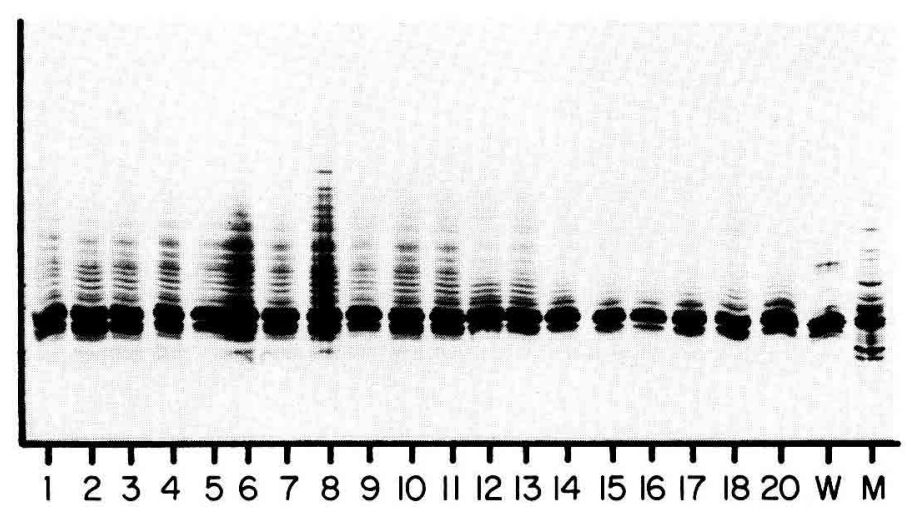

FIG. 4. - Isoelectrofocusing of samples obtained with diet $C$. See legend of figure 1.

transformed into products of lower MW which could be detected in the samples collected after $3 \mathrm{~h}$ of digestion. The electrophoretic band corresponding to serum albumin also disappeared after about $3 \mathrm{~h}$.

RIE was performed to quantitatively analyse the immunoreactive $\beta$ lactoglobulin and $\alpha$-lactalbumin leaving the abomasum. The $\beta$-lactoglobulin : $\alpha$ lactalbumin ratio was lower with the whey diet than with the milk diets (table 1); in the digesta, this ratio was already higher than in the three diets during the first 10 postprandial minutes (fig. 7). With the two milk diets, it decreased in the digesta during the next $10 \mathrm{~min}$. With the three diets, this ratio increased sharply during the 3rd postprandial hour, confirming that $\alpha$-lactalbumin disappeared after about $3 \mathrm{~h}$. 


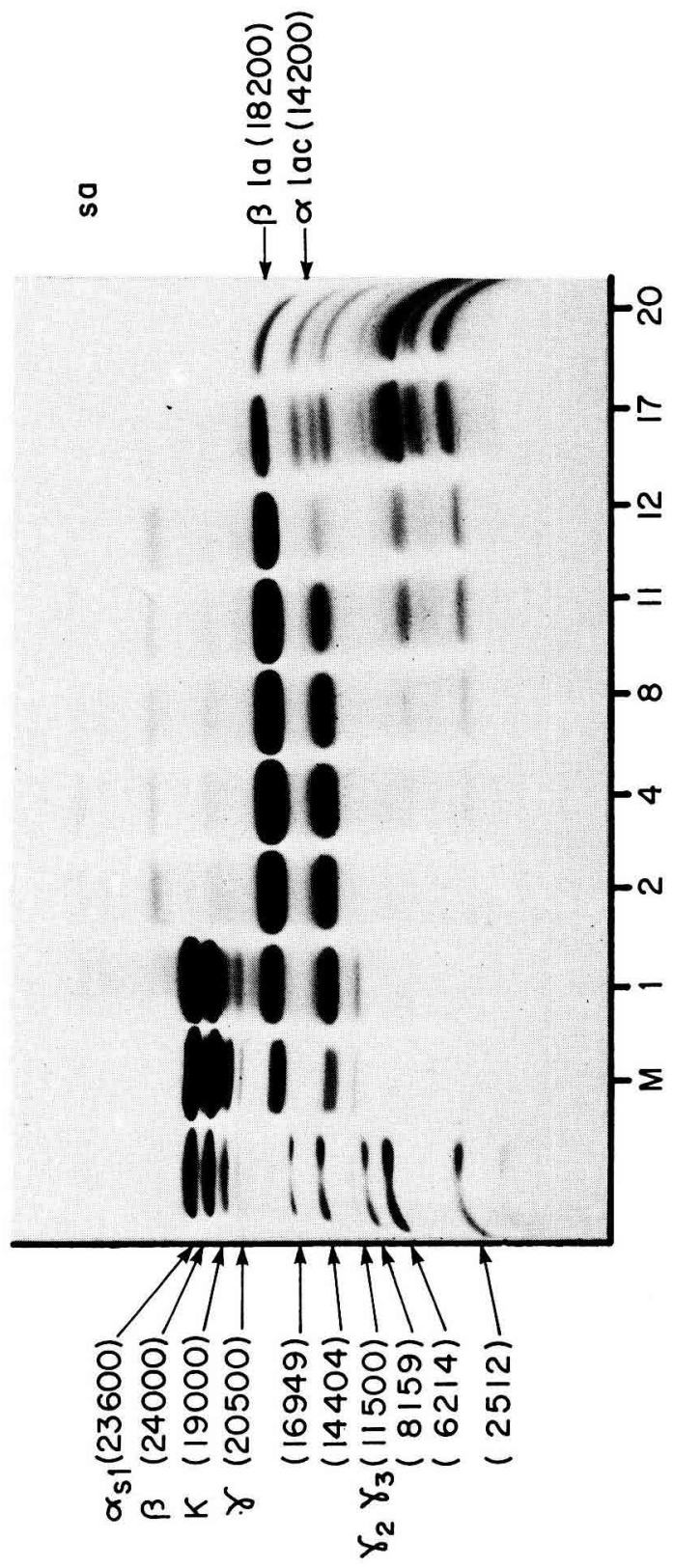

FIG. 5. - SDS-pore-gradient gel electrophoresis of samples obtained with diet B. R : molecular weight standard. $M$ : milk. See figure 1 for sample collection times. 


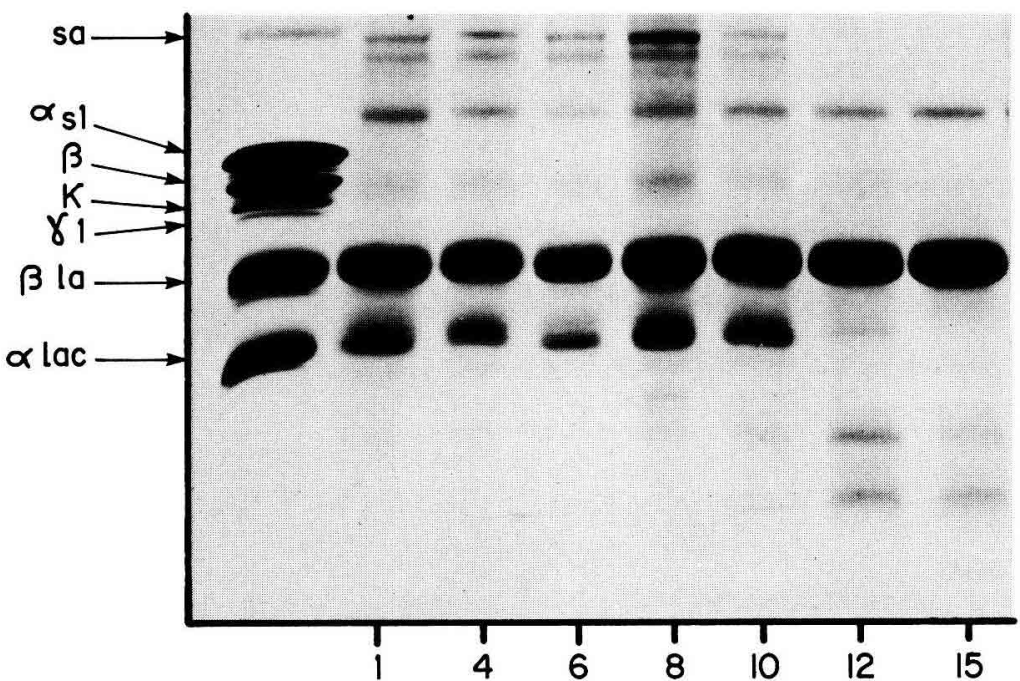

FIG. 6. - SDS-pore gradient gel electrophoresis of samples obtained with diet $C$. $M$ : milk. See figure 1 for sample collection times.

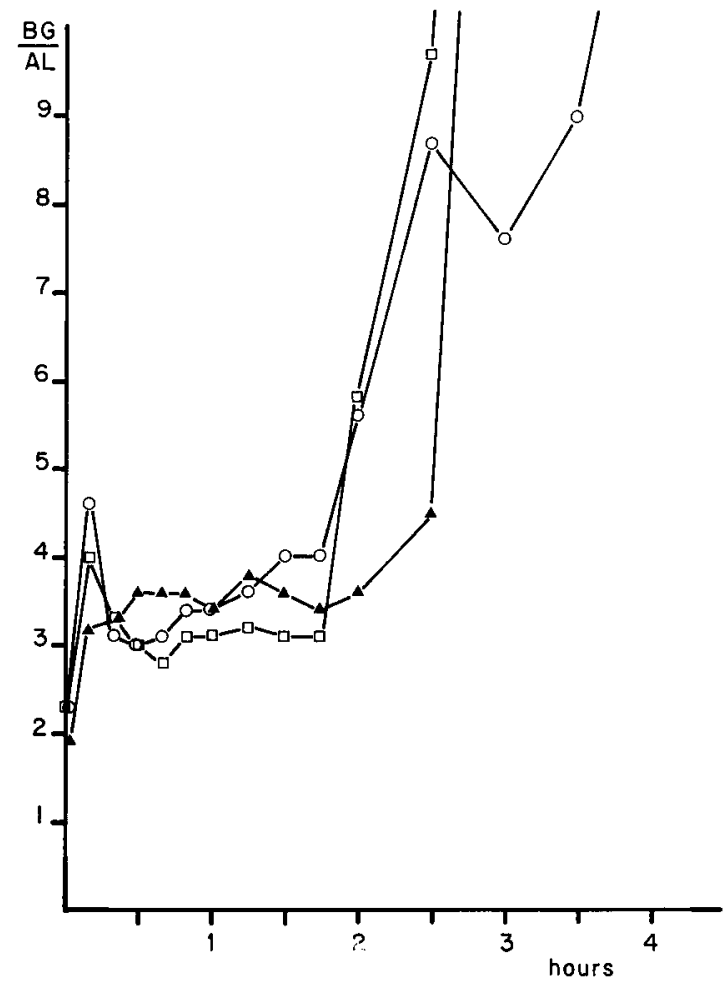

FIG. 7. - Relative quantities of $\beta$-lactoglobulin and $\alpha$-lactalbumin determining by RIE.

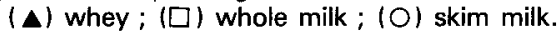


TABLE 1

Percentage of $\beta$-lactoglobulin and $\alpha$-lactalbumin determining by RIE in skim-milk and in casein and whey fractions obtained by acid precipitation of the skim-milk.

\begin{tabular}{lccc}
\hline & $\beta$-lactoglobulin & $\alpha$-lactalbumin & \multicolumn{1}{c}{$\beta$-lactoglobulin } \\
\hline Skim-milk & & & $\alpha$-lactalbumin \\
Casein & $3.3 \%$ & $1.5 \%$ & 2.2 \\
Whey & $1.1 \%$ & $0.3 \%$ & 3.4 \\
\hline
\end{tabular}

Results are given in \% of the freeze-dried product obtained from skim-milk, casein or whey.

\section{Discussion.}

The caseins coagulated quickly in the stomach since, after $10 \mathrm{~min}$ of digestion, the electrophoretic bands corresponding to them could not be detected in the effluent. However, it is not possible to say more exactly at which time coagulation was complete because all the products leaving the abomasum during the first $10 \mathrm{~min}$ were collected together.

After about $3 \mathrm{~h}$ of digestion, the peptide products which had migrated in PAGE with the front of migration came from casein proteolysis. These products were not visible with diet $C$, and they were similar to that obtained with calves fed casein solutions (Yvon et al., 1984). Although the milk diets contained minerals, the gastric emptying of these peptides was delayed compared to that obtained with calves fed caseins in mineral solution (Yvon et al., 1984). We observed about the same kinetics as with a casein diet without minerals. This delay in gastric emptying of peptide was probably induced by delayed proteolysis due to casein coagulation.

With the three diets, the results concerning the major whey proteins were similar. They showed differences between $\beta$-lactoglobulin and $\alpha$-lactalbumin. $\beta$ Lactoglobulin was present in all the samples collected, showing that this protein left the stomach relatively slowly and that gastric enzymes did not hydrolize it since the major product collected after $7 \mathrm{~h}$ of digestion was still $\beta$-lactoglobulin. In contrast, intact $\alpha$-lactalbumin was no longer present after $3 \mathrm{~h}$. As some low MW peptides are released with similar kinetics, these results indicate that $\alpha$ lactalbumin, which left the abomasum, was hydrolized by gastric enzymes. These results are in agreement with those of Jenkins et al. (1980) who showed in vitro that whey proteins are little proteolized at acid $\mathrm{pH}$. Otani (1981) evidenced in vitro that $\beta$-lactoglobulin is resistant to proteolysis because of its compact tertiary structure. 
With the three diets, the increase of the $\beta$-lactoglobulin : $\alpha$-lactalbumin ratio between the diets and the digesta collected before $3 \mathrm{~h}$ (fig. 7) could be explained by modifications of the $\alpha$-lactalbumin molecule. In PAGE, $\alpha$-lactalbumin gave several electrophoretic bands, and the densometric recording of all these bands gave similar $\beta$-lactoglobulin: $\alpha$-lactalbumin ratios in the digesta and the corresponding diets. These results indicate that the $\alpha$-lactalbumin was modified as its immunoreactive properties decreased. Such a modification could be explained by the action of gastric enzymes or by changes in the protein during its storage in TCA. $\alpha$-Lactalbumin seems to be more sensitive of TCA than the other major milk proteins. Partial deamination of the $\alpha$-lactalbumin in the TCA could explain why we observed only one electrophoretic band in SDS-PGGE and several in PAGE as well as modifications of the immunoreactive properties.

The relative increase of the proportion of $\beta$-lactoglobulin observed after about $3 \mathrm{~h}$ with the three diets corresponded to the disappearance of the intact $\alpha$ lactalbumin. In contrast, changes in the yield observed during the first 20 min, only with the two milk diets, could be explained by a preferential interaction between $\beta$-lactoglobulin and the caseins during coagulation (table 1). By RIE we observed (table 1) that the casein precipited at $\mathrm{pH} 4.6$ contained $1.1 \%$ of $\beta$ lactoglobulin and only $0.3 \%$ of $\alpha$-lactalbumin. The values obtained for $\beta$ lactoglobulin are in agreement with those of Douglas et al. (1981) who reported $0.8 \%$ of $\beta$-lactoglobulin in the casein. In these conditions, the $\beta$-lactoglobulin : $\alpha$ lactalbumin ratio was about 1.5 that found in the milk. These results could explain the increase observed in the digesta where caseins were detected. When the caseins coagulated in the stomach, a proportion of $\beta$-lactoglobulin must have been trapped with the caseins, inducing a decrease in the relative proportion of $\beta$ lactoglobulin in the samples collected.

The presence of fat did not modify the hydrolysis of milk proteins. Casein coagulation occurred very quickly and the peptides derived from the caseins, which arrived slowly in the duodenum, reflected a fairly high proteolysis. In particular, very acid peptides, probably corresponding to phosphopeptides, were detected. The presence of casein in the diet did not modify the gastric proteolysis of whey proteins. The $\beta$-lactoglobulin was poorly degraded or not at all, and $\alpha-$ lactalbumin was slowly but completely hydrolized after $3 \mathrm{~h}$ in some peptides which had lost their immunoreactive properties.

All these results have to be confirmed by studies of the amino acid compositions of peptide products which arrive in the duodenum and by identification of the structure and origin of these peptides.

Reçu en décembre 1983.

Accepté en mai 1984.

Résumé. Digestion in vivo du lait dans la caillette du veau. II. - Protéolyse du lait et du lactosérum.

Les produits peptidiques insolubles en TCA $12 \%$ récoltés dans le duodenum proximal de veaux à différents temps après l'ingestion de lait écrémé ou lactoserum ont été caractéri- 
sés par électrophorèse en gel de polyacrylamide, électrofocalisation et électrophorèse en présence de SDS. La $\beta$-lactoglobuline et l' $\alpha$-lactalbumine ont été dosées par rocket immunoélectrophorèse.

La présence de matière grasse ne modifie pas l'hydrolyse des protéines du lait. La coagulation des caséines se produit très rapidement et les peptides provenant des caséines, qui arrivent lentement dans l'intestin, indiquent une protéolyse importante. La présence de caś $^{\prime}$ ine dans l'aliment ne modifie pas la protéolyse des protéines du lactosérum. La $\beta$ lactoglobuline est peu ou pas dégradée alors que l' $\alpha$-lactalbumine est lentement mais complètement hydrolysée en peptides ayant perdu leur réactivité immunologique.

\section{References}

BERRIDGE N. J., DAVIS J. G., KON P. M., SPARTLING F. R., 1943. The production of rennet from living calves. J. Dairy Res., 13, 145-161.

DELFOUR A., ALAIS C., JOLLES P., 1966. Structure of cow's kappa caseino glycopeptide : the N terminal octapeptide. Chimia, 20, 148-150.

DOUGLAS F. W., GREENBERG R., FARREL H. M., EDMONSON L. E., 1981. Effect of UHT pasteurization on milk proteins. J. agric. Food Chem., 29, 11-15.

GARNOT P., TOULLEC R., THAPON J. L., MARTIN P., HOANG M. T., MATHIEU C. M., RIBADEAU-DUMAS B., 1977. Influence of age, dietary protein and weaning on calf abomasal enzymic secretion. J. Dairy Res., 44, 9-23.

GRIPON J. C., DESMAZEAUD M. J., LE BARS D., BERGERE J. L., 1975, - Etude du rôle des microorganismes et des enzymes au cours de la maturation des fromages. II. Influence de la présure commerciale. Le Lait, 55, 502-516.

JENKINS K. J., MAHADEVAN S., EMMONS B. D., 1980. Susceptibility of proteins used in calf milk replacers to hydrolysis by various proteolytic enzymes. Can. J. anim. Sci., 60, 907-914.

LAURELL C. L., 1966. Quantitative estimation of proteins by electrophoresis in agarose gel containing antibodies. Anal. Biochem., 15, 45-52.

OTANI H., 1981. Susceptibility of S-carboxymethylated b-lactoglobulin to peptic, tryptic and chymotryptic digestions. Jap. J. zootechn. Sci, 52, 689-691.

PÉlissieR J:-P., GUILLOTEAU P., BRULE G., TOULLEC R., 1983. Digestion des protéines du lait dans la caillette du veau préruminant. Evacuation gastrique après un repas d'épreuve. Reprod. Nutr. Dévelop., 23, 161-173.

PORCHER C., 1930. La méthode synthétique dans l'étude du lait. Le lait au point de vue colloïdal. Recherches sur le mécanisme d'action de la présure. Le Lait, 95, 509-528.

TRIEU-CUOT P., GRIPON J.-C., 1981. Electrofocusing and two dimensional electrophoresis of bovine caseins. J. Dairy Res., 48, 303-310.

URIEL J., 1966. Méthode d'électrophorèse dans les gels d'acrylamide-agarose. Bull. Soc. Chim. biol., 48, 969-982.

YVON M., PÉLISSIER J.-P., GUILLOTEAU P., TOULLEC R., 1984. In vivo milk digestion in the calf abomasum. I. Whole casein digestion. Reprod. Nutr. Dévelop., 24, 587-595. 